Original Article

\title{
Kolerasi Indeks Obesitasa dengan Kadar Neutrophil Gelatinase Associated Lipocalin (NGAL) pada Subyek Dewasa Non-Diabetes Melitus
}

\section{Correlation of Obesity Index with Neutrophil Gelatinase Associated Lipocalin (NGAL) Levels in Non Diabetes Mellitus Adults.}

\author{
Hardyansa*1, Liong Boy Kurniawan², Yuyun Widaningsih ${ }^{2}$ \\ ${ }^{1}$ Program Studi Magister Ilmu Biomedik, Pascasarjana, Universitas Hasanuddin, Indonesia \\ ${ }^{2}$ Departemen Ilmu Patologi Klinik, Fakultas Kedokteran, Universitas Hasanuddin, Indonesia \\ (hardyansahayat171095@gmail.com / 081991600125)
}

\begin{abstract}
ABSTRAK
Korelasi Indeks Obesitas Dengan Kadar Neuthrophil Gelatinase Associated Lipocalin (NGAL) Pada Subjek Dewasa Non-Diabetes Melitus. (Dibimbing oleh Liong Boy Kurniawan dan Yuyun Widaningsih). Penelitian ini bertujuan untuk mengetahui kolerasi indeks obesitas dengan kadar Neuthrophil Gelatinase Associated Lipocalin (NGAL) pada subjek dewasa Non-Diabetes Melitus. Sebanyak 70 sampel yang memenuhi kriteria inklusi dan eksklusi, terdiri dari 17 laki-laki obesitas, 18 laki-laki non-obesitas, 17 perempuan obesitas, dan 18 perempuan non obesitas. Metode penelitian ini adalah cross sectional study. Hasil penelitian ini menunjukkan bahwa tidak terdapat korelasi antara Neuthrophil Gelatinase Associated Lipocalin dengan IMT ( $=0,241, r=0,142)$, PP $(p=0,204, r=-$ $0,154), \%$ Lemak Tubuh $(p=0,984, r=-0,02)$, LemakVisceral $(p=0,955 r=0,007)$ pada subjek dewasa non diabetes melitus. Kesimpulan penelitian yaitu tidak ada kolerasi indeks obesitas dengan kadar Neuthrophil Gelatinase Associated Lipocalin pada subjek dewasa non diabetes melitus (DM).
\end{abstract}

Kata kunci : Neutrophil Gelatinase Associated Lipocalin (NGAL), Indeks Massa Tubuh, Lingkar Pinggang, Persen Lemak Tubuh, Lemak Visceral.

\begin{abstract}
Obesity Index Correlation with Neuthrophil Gelatinase Associated Lipocalin (NGAL) Levels in NonDiabetes Mellitus Adult Subjects. (Supervised by Liong Boy Kurniawan and Yuyun Widaningsih). This study aims to determine the correlation between obesity index and levels of Neuthrophil Gelatinase Associated Lipocalin (NGAL) in adult subjects with non-diabetes mellitus. A total of 70 samples met the inclusion and exclusion criteria, consisting of 17 obese men, 18 non-obese men, 17 obese women, and 18 non-obese women. This research method is a cross sectional study. The results of this study indicate that there is no correlation between Neuthrophil Gelatinase Associated Lipocalin and BMI $(\mathrm{p}=$ $0.241, r=0.142), L P(p=0.204, r=-0.154), \%$ Body Fat $(p=0.984, r=-0.02)$, Visceral Fat $(p=0.955$ $r=0.007)$ in non-diabetic adult subjects. From the results of this study, it can be concluded that there is no correlation between obesity index and levels of Neuthrophil Gelatinase Associated Lipocalin in nondiabetic adult subjects (DM).
\end{abstract}

Keywords : Neutrophil Gelatinase Associated Lipocalin (NGAL), Body Mass Index, Waist Circumference, \% Body Fat, Visceral Fat.

https://doi.org/10.33860/jik.v15i4.827

(C) 2021 by the authors. Submitted for possible open access publication under the terms and conditions of the Creative Commons Attribution (CC BY SA) license (https://creativecommons.org/licenses/by-sa/4.0/). 


\section{PENDAHULUAN}

Obesitas yaitu keadaan tubuh yang gemuk akibat kelebihan lemak yang pada umumnya di timbun dalam jaringan subkutan (bawah kulit). Di sekitar organ tubuh dan kadang terjadi ${ }^{1}$. Obesitas sentral adalah peningkatan lemak tubuh yang lokasinya lebih banyak di daerah abdominal dari pada di daerah pinggul, paha atau lengan ${ }^{2}$. Obesitas sentral dapat terjadi akibat adanya ketidakseimbangan energi yang berasal dari tingginya asupan makanan dan sedikit aktivitas fisik, meskipun obesitas sentral dapat terjadi berdasarkan variasi genetik ${ }^{3}$. Berdasarkan dari Laporan Riset Kesehatan Dasar (Riskesdas) pada tahun 2013, prevalensi obesitas pada penduduk berusia $\geq 18$ tahun berdasarkan Indeks Massa Tubuh (IMT) adalah $15,4 \%$. Prevalensi penduduk laki-laki dewasa obesitas pada tahun 2013 sebanyak 19,7 persen, lebih tinggi dari tahun $2007(13,9 \%)$ dan tahun 2010 (7,8\%). Pada tahun 2013, prevalensi obesitas perempuan dewasa (>18 tahun) 32,9 persen, naik 18,1 persen dari tahun $2007(13,9 \%)$ dan 17,5 persen dari tahun $2010(15,5 \%)^{4}$.

Terkait dengan peningkatan risiko penyakit degeneratif sangat berkaitan berat dengan obesitas sentral. Obesitas sentral ini mengalami terjadinya penumpukan lemak terutama pada area bagian perut yang diukur dengan cara menggunakan indikator lingkar perut. Lemak visceral merupakan lemak tubuh yang terkumpul di bagian sentral tubuh dan melingkupi organ internal. Akibat dampak yang dapat ditimbulkan dari kelebihan lemak viseral berkolerasi erat dengan peningkatan risiko penyakit kardiovaskuler, sindrom metabolik seperti keadaan hipertensi, dislipidemia, dan diabetes tipe II, dan resistensi insulin ${ }^{5}$. Obesitas dapat berkolerasi dengan terjadinya proses inflamasi. Pada jaringan adiposa melimpahnya trigliserida akan merangsang sel adiposit mensekresi sitokin yang disebut adipokin. Kemudian adipokin akan mengaktivasi monosit menjadi makrofag. Adipokin merupakan sitokin yang berkontribusi di dalam inflamasi sistematik, contohnya pada tumor necrosis factor-alpha (TNF-a), amino petin, leptin, resisten dan interleukin. Pada obesitas kondisi sitokin akan mengalami peningkatan ${ }^{6}$.

Lemak atau yang juga dikenal dengan nama lipid merupakan suatu senyawa yang tidak dapat larut dalam air. Naiknya berat badan di sebabkan oleh menumpuknya lemak pada bagian tubuh tertentu akibat pasokan sumber makanan yang di cerna secara berlebihan dan terhambat akibat kurangnya aktifitas tubuh ${ }^{7}$. Lipid atau lemak merupakan sekelompok senyawa hesterogen yang terkait dengan asam lemak kemudian disimpan di dalam tubuh sebagai sumber energi. Lemak tubuh memiliki kolerasi erat terhadap indeks masa tubuh (IMT) karena nilai IMT yang tinggi dapat mengindikasi lemak tubuh yang lebih tinggi. Lemak tidak terdistribusi secara merata di seluruh tubuh. Deposit terbesar lemak terletak di area subkutan sebagai lemak subkutan yaitu $80 \%$ dari seluruh lemak tubuh, sementara sisanya di viseral sebagai lemak viseral yang terdapat dalam rongga abdomen dan rongga dada ${ }^{8}$. Lemak tubuh sendiri merupakan sumber energi bagi manusia dalam melakukan aktivitas setiap harinya. Dampak lemak yang berlebih akan memicu terjadinya obesitas dan lebih berisiko menimbulkan berbagai penyakit. Tidak hanya lemak tubuh saja yang dapat memicu timbulnya berbagai penyakit akibat kelebihan lemak pada manusia namun ada juga lemak lainnya seperti lemak viseral ${ }^{9}$. Lemak viseral merupakan lemak yang posisinya terdapat di dalam rongga perut dan berada di sekitaran hati, pankreas dan usus. Lemak ini salah satu jenis lemak yang jaringannya aktif. Lemak viseral tidak hanya tertumpuk di bagian perut, tetapi juga dapat melepaskan hormon yang dapat memicu terjadinya peradangan ${ }^{9}$.

Neutrophil galatinase associated lipocalin (NGAL) biasanya pada penderita gangguan ginjal akut kadarnya pada urine dapat meningkat dengan cepat dan lebih awal dibandingkan dengan peningkatan kadar kreatinin serum sehingga lipocalin dapat dikaitkan dengan penanda pada diagnosis gangguan ginjal akut. Pada gangguan ginjal akut biasanya terdapat penurunan fungsi ginjal secara tiba-tiba dengan peningkatan kreatinin serum di atas atau $>1,5$ kali dari kadar yang sebelumnya atau terjadi penurunan pada urine output $(\mathrm{UO})<0,5 \mathrm{ml} / \mathrm{jam}$ selama enam jam ${ }^{10}$. Neutrophil galatinase associated lipocalin (NGAL) awalnya di identifikasi sebagai protein fase akut yang konsentrasinya meningkat dalam darah sebagai respon terhadap gangguan inflamasi (respon fase akut), disekresikan dari neutrofil selama infeksi bakteri. Kadar NGAL atau ekspresinya dapat meningkat pada ginjal setelah terjadinya cedera karena berbagai sebab 11.

Penelitian ini bertujuan untuk mengetahui kolerasi indeks obesitas dengan 
kadar Neuthrophil Gelatinase Associated Lipocalin (NGAL) pada subjek dewasa Non Diabetes Melitus.

\section{METODE PENELITIAN}

Pengumpulan sampel dilakukan di Laboratorium Patologi Klinik Rumah Sakit Perguruan Tinggi Negeri Universitas Hasanuddin (RSPTN UH). Jenis penelitian yang digunakan adalah observational dengan menggunakan desain cross sectional study. Populasi dalam penelitian ini adalah indeks obesitas non diabetes mellitus (DM) dengan kriteria lingkar pinggang laki-laki adalah $\geq 90$ $\mathrm{cm}$ dan pada perempuan $\geq 80 \mathrm{~cm}$ dan subjek laki-laki dan perempuan dengan lingkar pinggang normal non DM. Jenis dan cara pengambilan sampel yang digunakan dalam penelitian ini adalah non-probability sampling secara purposive sampling. Jumlah minimal sampel dalam penelitian ini adalah 28 pada setiap kelompok, kelompok obesitas 28 sampel dan non obesitas melitus 28 sampel. Sehingga total sampel dalam penelitian ini adalah 56 sampel. Peneliti menentukan 70 subyek untuk dianalisis.

Analisis data dilakukan menggunakan perangkat lunak statistik berlisensi (SPSS versi
25). Metode statistik yang digunakan adalah perhitungan statistik deskriptif (range, median, mean, standar deviasi dan sebaran data) dan uji statistik. Uji statistik digunakan berdasarkan analisis sebaran data untuk menilai normalitas data penelitian. Hasil uji statistik signifikan jika nilai $\mathrm{p}<0,05$ (tingkat sensitivitas yang ditentukan peneliti adalah $95 \%$, atau standard error 5\%).

\section{HASIL}

Penelitian ini dilakukan pada November 2021 di Laboratorium Penelitian Rumah Sakit Perguruan Tinggi Negeri Universitas Hasanuddin (RSPTN UH) Makassar. Sebanyak 70sampel yang memenuhi kriteria inklusi dan eksklusi, terdiri dari 17 laki-laki obesitas, 18 laki-laki non-obesitas, 17 perempuan obesitas, dan 18 perempuan non obesitas, dengan kisaran umur $23-\leq 40$ tahun dan rerata umur 30 tahun (Tabel 1).

Tabel 2 menunjukkan bahwa nilai $\mathrm{p}$ pada variabel, IMT, lingkar pinggang, \% lemak tubuh, dan lemak visceral > 0,05, sehingga dapat disimpulkan bahwa tidak ada kolerasi IMT, lingkar pinggang, \% lemak tubuh, lemak visceral dengan kadar Neuthrophil Gelatinase Associated Lipocalin.

Tabel 1. Karesteristik Responden

\begin{tabular}{|c|c|c|c|}
\hline Variabel & Mean \pm SD & Median & Min-Max \\
\hline Usia (tahun) & $31,23 \pm 4,32$ & 31,00 & $19,84-24,63$ \\
\hline IMT $(\mathrm{kg} / \mathrm{m} 2)$ & $25,90 \pm 3,76$ & 24,89 & $19,73-34,48$ \\
\hline Lingkar pinggang $(\mathrm{cm})$ & $86,66 \pm 10,75$ & 87,00 & $68-110$ \\
\hline$\%$ Lemak tubuh & $31,12 \pm 8,72$ & 32,300 & $9,30-49,70$ \\
\hline Lemak visceral & $11,66 \pm 7.24$ & 10,00 & $2,00-30,00$ \\
\hline NGAL (ng/dL) & $21,85 \pm 1,67$ & 21,81 & $19,84-24,63$ \\
\hline
\end{tabular}

Tabel 2 Korelasi IMT, LingkarPinggang, \% Lemak Tubuh, Lemak Visceral dan Kadar Neuthrophil Gelatinase Associated Lipocalin NGAL)

\begin{tabular}{ccc}
\hline Variabel & $\boldsymbol{r}$ & $\boldsymbol{p}$ \\
\hline IMT $(\mathrm{kg} / \mathrm{m} 2)$ & 0,142 & 0,241 \\
Lingkar pinggang $(\mathrm{cm})$ & 0,154 & 0,204 \\
\% Lemak tubuh & 0,002 & 0,984 \\
Lemak visceral & 0,007 & 0,955 \\
\hline
\end{tabular}




\section{PEMBAHASAN}

Hasil penelitian lingkar pinggang dan kadar Neuthrophil Gelatinase Associated Lipocalin (NGAL) di dapatkan hasil $(\mathrm{p}=0,024)$ yang menunjukkan bahwa tidak ada kolerasi lingkar pinggang dengan kadar NGAL. Pada hasil penelitian kolerasi \% lemak tubuh dengan kadar NGAL di dapatkan nilai $(\mathrm{p}=0,984)$, tidak terdapat kolerasi lemak tubuh dengan kadar NGAL. Serta kolerasi lemak visceral dan Neuthrophil Gelatinase Associated Lipocalin (NGAL) $(\mathrm{p}=0,955)$ yang menunjukkan tidak ada kolerasi lemak visceral dengan kadar NGAL.

Salah satu alasan yang kuat penelitian yang saya lakukan dimana tidak adanya korelasi pada indeks obesitas dengan kadar Neuthrophil Gelatinase Associated Lipocalin (NGAL) yaitu pada penelitian ini menggunakan subjek dewasa non diabetes melitus dan mempunyai kadar glukosa yang rata-rata dalam batas normal, berbanding terbalik dengan penelitian sebelumnya yang dilakukan oleh El-Mesallamy HO dkk ${ }^{12}$ yang menggunakan subjek diabetes, dimana pada penelitian ini dapat di simpulkan bahwa subjek diabetes mengalami peningkatan kadar serum NGAL. Obesitas, ditentukan oleh IMT, berkorelasi tidak signifikan dengan kadar NGAL dalam penelitian ini. Sedangkan pada penelitian lain yang dilakukan oleh Wang Y dkk 13 bertentangan dengan penelitian yang dilakukan oleh El-Mesallamy HO dkk dimana ditemukan hasil korelasi positif yang kuat antara Neuthrophil Gelatinase Associated Lipocalin (NGAL) dan IMT. Selain itu, peneliti tidak menemukan perbedaan yang signifikan dalam kadar NGAL antara subjek obesitas dan non obesitas dengan diabetes. Penelitian ini sebanding dengan temuan El-mesallamy yang menemukan bahwa IMT meningkat secara signifikan pada subjek perempuan dengan diabetes dibandingkan dengan Laki-laki dalam kelompok yang sama ${ }^{12,13}$.

Selain itu pada penelitian lainnya diketahui bahwa tidak ada perbedaan signifikan Neuthrophil Gelatinase Associated Lipocalin (NGAL) antara obesitas dan non obesitas pada subjek dengan diabetes. Ini sebanding dengan temuan El-Mesallamy $\mathrm{HO}$ dkk ${ }^{12}$ yang menemukan bahwa nilai IMT secara signifikan meningkat pada subjek perempuan dengan diabetes dibandingkan dengan laki-laki dalam kelompok yang sama.

Hasil penelitian ini didapatkan nilai $(\mathrm{p}=0,241)$ yang menunjukkan bahwa IMT dan kadar Neuthrophil Gelatinase Associated Lipocalin (NGAL), tidak ada kolerasi pada kedua subjek variabel. Pada hasil penelitian lainnya menurut El-Mesallamy $\mathrm{HO}$ dkk ${ }^{12}$ Pengaruh obesitas dan kontrol glikemik pada serum NGAL dan sumbu faktor pertumbuhan seperti insulin pada subjek diabetes tipe 2 dan pada penelitian Wang Y dkk ${ }^{13}$ yaitu pada Lipocalin-2 Adalah Penanda Peradangan yang Berkolerasi erat dengan Obesitas, Resistensi Insulin, dan Hiperglikemia pada Manusia yang menemukan korelasi positif yang kuat antara NGAL dan BMI antara obesitas dan non obesitas pada subjek dengan diabetes. Ini sebanding dengan temuan El-Mesallamy HO dkk ${ }^{12}$ yang menemukan bahwa nilai IMT secara signifikan meningkat pada subjek perempuan dengan diabetes dibandingkan dengan laki-laki dalam kelompok yang sama.

Neuthrophil Gelatinase Associated Lipocalin (NGAL) sebagai adipokin memiliki respon imun bawaan yang di pasangkan dengan fungsi protektif pada peradangan kronis dan pada sistem saluran pernapas. Ini memiliki peran sebagai biomarker untuk cedera ginjal. Dalam kaitannya dengan komplikasi diabetes seperti aterosklerosis, bukti terbaru menunjukkan bahwa NGAL berperan penting dalam remodeling vaskular dan ketidak stabilan plak khususnya NGAL diekspresikan dalam makrofag. Neuthrophil Gelatinase Associated Lipocalin (NGAL) memiliki peran penting dalam homeostasis glukosa dan insulin sensitivitas ${ }^{14}$.

Pada penelitian sebelumnya yang dilakukan oleh Areej E. Elkhidir, Halima B. Eltaher, dan Abdelrahim O. Mohamed menunjukkan Neuthrophil Gelatinase Associated Lipocalin (NGAL) ditemukan secara signifikan lebih tinggi pada subjek dengan diabetes tipe $2(\mathrm{p}=0,001)$.. Perempuan memiliki nilai IMT yang lebih tinggi dibandingkan dengan Laki-laki di kelompok subjek $(\mathrm{p}<0,001)$. HbA1c, kreatinin serum, LDL dan kolesterol total meningkat pada subjek dengan diabetes. tes $(p<0,02)$. HDL lebih rendah pada subjek $(\mathrm{p}=0,002)$. Peningkatan HbA1c yang signifikan ditemukan pada subjek laki-laki $(\mathrm{p}=0,028)$ dibandingkan dengan subjek perempuan. Subjek selanjutnya diklasifikasikan menjadi diabetes terkontrol, tidak terkontrol, obesitas dan non-obesitas. Ada peningkatan yang signifikan pada lingkar pinggang pada penderita diabetes yang tidak terkontrol dibandingkan dengan yang 
dikendalikan. NGAL tidak memiliki perubahan signifikan antara penderita diabetes terkontrol dan tidak terkontrol atau non-obesitas dan pada subjek obesitas ${ }^{12}$.

\section{KESIMPULAN DAN SARAN}

Kesimpulkan penelitian yaitu tidak ada kolerasi indeks obesitas dengan kadar Neuthrophil Gelatinase Associated Lipocalin pada subjek dewasa non diabetes melitus (DM).

Bagi peneliti selanjutnya disarankan dapat melakukan pengembangan penelitian mengenai kolerasi indeks obesitas dengan kadar NGAL (Neuthrophil Gelatinase Associated Lipocalin) pada subjek dewasa menggunakan sampel serum, urine, dan saliva pada responden yang memiliki riwayat diabetes melitus dan penyakit kardiovaskular, seperti DM tipe II, hipertensi, dan hiperglikemia.

\section{DAFTAR PUSTAKA}

1. Misnadierly, 2007. Obesitas Sebagai Faktor Resiko Berbagai Penyakit. Jakarta : Pustaka Obor Papuler

2. Soegih, R. Rachmad, and Kunkun K Wiramihardja. 2009. "Obesitas: Permasalahan Dan Terapi Praktis." 1st ed. Jakarta: Sagung Seto.

3. Després, Jean-Pierre. 2006. "Abdominal Obesity: The Most Prevalent Cause of the Metabolic Syndrome and Related Cardiometabolic Risk." European Heart Journal Supplements 8(suppl_B): B4-12.

4. KEMENKES, Kementerian Kesehatan Republik Indonesia. 2019. Batas Ambang Indeks Masa Tubuh." Direktorat Pencegahan Dan Pengendalian Penyakit Tidak Menular Kementerian Kesehatan Republik Indonesia.

5. Bertin, B., Desreumaux, P. \& Dubuquoy, L. Obesity, visceral fat and Crohn' $\mathrm{s}$ disease. (2010). doi:10,1097/MCO.0b013e32833cf0f4

6. Listiyana, Aulia Dewi, Mardiana Mardiana, and Galuh Nita Prameswari. 2013. "Obesitas Sentral Dan Kadar Kolesterol Darah Total." Jurnal Kesehatan Masyarakat 9(1): 37-43.

7. Jansen, 2016. Ketahui Kadar Lemak Tubuh anda, avalaible from http://www.askjansen.com/kadar-lemak-tubuh/, accesed tanggal 5 Desember 2016.

8. Dewi Up, Dieny Ff. Hubungan antara densitas energi dan kualitas diet dengan indeks massa tubuh (IMT) pada remaja Journal of Nutrition College 2013, 2 (4);445-57.

9. Droletet al.(2008).Hypertrophy and Hyperplasia of Abdominal Adipose Tissues in
Women.International Journal of Obesity : Nature Publishing Group.

10. Mustakin. 2016. "Analisis Kadar Adiponektin Dan Lipocalin-2 Serum Pada Subyek Obesitas Sentral Dengan Prediabetes.” Tesis. Makassar: Pendidikan Dokter Spesialis Universitas Hasanuddin.

11. Daniels L.B, Barrett-Connor E, Clopton P, Laughlin G.AJoachim H. Maisel A.S, 2012, "Plasma Neutrophil Gelatinase-Associated Lipocalin Is Independently Associated With Cardiovascular Disease and Mortality in Community-Dwelling Older Adults", in :Journal of the American College of Cardiology Vol. 59, No. 12, p: 1101-1109.

12. El-Mesallamy HO, Hamdy NM, Sallam AA. Efek obesitas dan glikemik kontrol pada serum lipocalin dan sumbu faktor pertumbuhan seperti insulin dalam tipe 2 subjek diabetes. Akta

Diabetes. 2013;50(5):67985. doi:10,1007/s005 92-012-0373-6 .

13. Wang Y, Lam KS, Kraegen EW, Sweeney G, Zhang J, Tso AW, et al. Lipocalin-2 is an inflammatory marker closely associated with obesity, insulin resistance, and hyperglycemia in humans. Clin Chem. 2007;53(1):34-41. doi: 10,1373/clinchem.2006.075614.

14. Mishra J, Ma Q, Prada A, Mitsnefes M, Zahedi $\mathrm{K}$, Yang J, dkk. Identifikasilipocalin terkait gelatinase neutrofil sebagai bioteknologi urin awal yang baru penanda untuk cedera ginjal iskemik. J Am Soc Nephrol. 2003;14(10):2534-43 